\title{
ANALISIS KELAYAKAN FINANSIAL USAHA PEMBIBITAN KELAPA SAWIT PADA UD. JAYA TANI KECAMATAN KARANG BARU KABUPATEN ACEH TAMIANG
}

\author{
Siti Balqies Indra ${ }^{1}$, Rozalina ${ }^{2}$ dan Ozy Fahmi Nudin ${ }^{2}$ \\ ${ }^{1}$ Dosen Fakultas Pertanian Universitas Samudra \\ ${ }^{2}$ Dosen Fakultas Pertanian Universitas Samudra \\ ${ }^{2}$ Mahasiswa Program Studi Agribisnis Fakultas Pertanian Universitas Samudra
}

\begin{abstract}
Abstrak
Tujuan penelitian untuk menganalisis kelayakan finansial usaha pembibitan kelapa sawit pada UD. Jaya Tani Kecamatan Karang Baru Kabupaten Aceh Tamiang. Penelitian ini menggunakan metode survei dengan studi kasus pada UD. Jaya Tani Kecamatan Karang Baru Kabupaten Aceh Tamiang. Penelitian dilakukan pada bulan November s/d Desember 2017. Hasil penelitian produksi bibit kelapa sawit pada UD. Jaya Tani Kecamatan Karang Baru Kabupaten Aceh Tamiang selama tahun 2013 s/d 2017 adalah 29.025 bibit. Nilai produksi atau total penerimaan pada UD. Jaya Tani Kecamatan Karang Baru Kabupaten Aceh Tamiang selama tahun 2013 s/d 2017 adalah Rp.435.375.000,-. Pendapatan bersih pada UD. Jaya Tani Kecamatan Karang Baru Kabupaten Aceh Tamiang selama tahun 2013 s/d 2017 adalah Rp. 127.793.000,-.

Hasil analisis finansial diperoleh nilai NVP sebesar Rp.187.484.268,96 dimana nilai NPV lebih besar dari 0, artinya dari sisi kriteria investasi NPV usaha pembibitan kelapa sawit pada UD. Jaya Tani Kecamatan Karang Baru Kabupaten Aceh Tamiang layak untuk dikerjakan. Nilai IRR sebesar $14,42 \%$ dimana nilai ini lebih besar dari bunga bank berlaku sebesar $12 \%$, artinya dari sisi kriteria investasi IRR usaha pembibitan kelapa sawit pada UD. Jaya Tani Kecamatan Karang Baru Kabupaten Aceh Tamiang layak dikerjakan. Nilai Net B/C sebesar 1,57 dimana nilai Net B/C lebih besar dari 1, artinya dari sisi kriteria investasi Net B/C usaha pembibitan kelapa sawit pada UD. Jaya Tani Kecamatan Karang Baru Kabupaten Aceh Tamiang layak untuk dikerjakan. Nilai PBP sebesar 1,36 tahun dimana lebih kecil dari umur proyek 5 tahun, artinya dari sisi kriteria investasi PBP usaha pembibitan kelapa sawit pada UD. Jaya Tani Kecamatan Karang Baru Kabupaten Aceh Tamiang layak untuk dikerjakan. Kesimpulan dari empat kriteria investasi usaha pembibitan kelapa sawit pada UD. Jaya Tani Kecamatan Karang Baru Kabupaten Aceh Tamiang layak untuk dikerjakan.
\end{abstract}

Kata Kunci: Pembibitan, kelapa sawit, kelayakan, finansial

\section{PENDAHULUAN}

Usaha pembibitan merupakan usaha untuk memperbanyak tanaman baik secara generatif (biji) maupun secara vegetatif (stek, cangkok, okulasi, sambung) agar memperoleh bahan tanaman yang baru menggantikan tanaman yang tua atau rusak. Usaha pembibitan merupakan upaya penyediaan bibit tanaman bagi usahatani yang dikelola oleh masyarakat maupun perusahaan. Usaha pembibitan umumnya memperbanyak tanaman tahunan yang memerlukan waktu relatif menyiapkan bibit hingga siap untuk dipindahkan ke areal penanaman.

Usaha pembibitan tanaman merupakan usaha untuk memenuhi permintaan masyarakat terhadap bibit terutama bibit berlabel. Bibit berlabel adalah bibit yang telah mendapat sertifikat dari Instansi Penyelenggara 
Sertifikasi atau Balai Pengawasan dan Sertifikasi Benih (BPSB) dan telah teruji kebenarannya.

Kabupaten Aceh Tamiang merupakan kabupaten yang mempunyai lahan tanaman kelapa sawit yang dapat dikembangkan lebih luas. Usaha pembibitan harus didasarkan dengan memproduksi bibit tanaman yang mempunyai kualitas baik, agar apabila ditanam pada areal yang luas akan menghasilkan produksi yang baik pula. Usaha pembibitan kelapa sawit UD.Jaya Tani berada di Kecamatan Karang Baru adalah salah satu penangkaran bibit yang ada di Kabupaten Aceh Tamiang yang mengusahakan jenis komoditi kelapa sawit. Usaha ini menyediakan bibit kelapa sawit untuk wilayah Kabupaten Aceh Tamiang dan sebagian Kabupaten Aceh Timur. Prospek usaha pembibitan kelapa sawit UD.Jaya Tani dimasa mendatang yang masih terbuka peluang untuk meningkatkan pengembangan kegiatan. Luas lahan, produksi dan produktivitas tanaman kelapa sawit di Aceh Tamiang dapat dilihat pada tabel berikut.

Tabel I-1. Luas Lahan, Produksi dan Produktivitas Kelapa Sawit di Kabupaten Aceh Tamiang, 2017

\begin{tabular}{|c|l|r|r|r|r|}
\hline \multirow{2}{*}{ No } & \multicolumn{1}{|c|}{ Kecamatan } & \multicolumn{2}{|c|}{$\begin{array}{c}\text { Luas Lahan }(\mathrm{Ha}) \\
\text { Produksi }\end{array}$} & $\begin{array}{c}\text { Produktivitas } \\
\text { (Ton) }\end{array}$ \\
\cline { 3 - 4 } & \multicolumn{1}{c|}{ TBM } & \multicolumn{1}{c|}{ TM } & \multicolumn{1}{c}{ (Ton) } \\
\hline 1 & Tamiang Hulu & 548,00 & $3.855,00$ & $44.332,50$ & 11,50 \\
2 & Bandar Pusaka & 575,00 & $1.334,00$ & $16.008,00$ & 12,00 \\
3 & Kejuruan Muda & 165,00 & 689,00 & $8.130,00$ & 11,80 \\
4 & Tenggulun & $1.385,00$ & $2.170,00$ & $25.823,00$ & 11,90 \\
5 & Rantau & 88,00 & 438,00 & $5.037,00$ & 11,50 \\
6 & Kota Kuala Simpang & - & 10,00 & 115,00 & 11,50 \\
7 & Seruway & 250,00 & $3.082,00$ & $37.600,40$ & 12,20 \\
8 & Bendahara & 253,00 & $10.015,00$ & $123.184,50$ & 12,30 \\
9 & Banda Mulia & 110,00 & 170,00 & $2.040,00$ & 12,00 \\
10 & Karang Baru & 158,00 & 993,00 & $13.107,60$ & 13,20 \\
11 & Kekerak & 146,00 & 290,00 & $3.335,00$ & 11,50 \\
12 & Manyak Payed & 408,00 & 690,00 & $8.211,00$ & 11,90 \\
\hline Total & $4.086,00$ & $23.736,00$ & $286.924,00$ & 143,30 \\
\hline Rata-Rata & 340,50 & $1.978,00$ & $23.910,33$ & 11,94 \\
\hline
\end{tabular}

Sumber: BPS Aceh Tamiang, 2018

Tabel di atas menunjukkan bahwa luas lahan kelapa sawit di Kabupaten Aceh Tamiang adalah 23.736,00 hektar tanaman menghasilkan dan 4.086,00 hektar tanaman belum menghasilkan. Produksi 286.924,20 ton serta produktivitas 11,94 ton/hektar/tahun. Hal ini menunjukkan bahwa peluang usaha pembibitan kelapa sawit masih menjanjikan untuk dikerjakan guna memenuhi kebutuhan bibit petani yang sudah banyak memasuki akhir umur ekonomis tanaman kelapa sawit miliknya.

Pengelolaan pembibitan sangat perlu dilakukan karena merupakan langkah awal untuk menyiapkan bahan tanam yang sehat dan bermutu dan didalampelaksanaanya pembibitan harus betul-betul dilaksanakan sesuai teknis dan mengikuti aturan yang telah ditentukan. Dalam rangka menunjang pengembangan usaha pembibitan perlu 
dilakukan studi kelayakan usaha yang dapat digunakan sebagai informasi dan pengetahuan serta bahan pertimbangan bankdalam membiayai pengembangan usaha pembibitan tanaman.

Analisis finansial merupakan bahan pertimbangan layak atau tidak pelaksanaan suatu usaha. Pengertian layak dalam penelitian ini adalah manfaat (benefit) yang diperoleh dari pelaksanaan usaha (Ibrahim, 2003: 32). Analisis kelayakan finansial usaha pembibitan kelapa sawit pada UD.Jaya Tani ini bertujuan untuk menilai sejauh mana manfaat secara finansial yang diterima melalui usaha tersebut dari awal pelaksanaan proyek hingga sekarang, sebagai dasar layak atau tidak usaha dilaksanakan. Kenaikan harga jual atau merosotnya pemasaran yang mempengaruhi penerimaan, kenaikan inflasi yang akan mempengaruhi discount rate, meningkatnya bahan-bahan atau barangbarang tertentu secara relatif yang mempengaruhi biaya, semuanya hendak diperhitungkan terlebih dahulu (Soetrisno, 2001: 25).

Untuk melakukan analisis keuangan tersebut digunakan beberapa asumsi dan parameter keuangan yang didasarkan pada hasil pengamatan di lapangan, masukan dari instansi terkait dan pustaka yang mendukung sehingga akan diperoleh gambaran secara utuh tentang aspek keuangan usaha pembibitan tanaman kelapa sawit. Berdasarkan uraian pada latar belakang di atas maka penulis tertarik dan merasa penting untuk melakukan penelitian tentang analisakelayakan finansial usaha pembibitan kelapa sawit pada UD.Jaya Tani di Kecamatan Karang Baru Kabupaten Aceh Tamiang.

\section{Identifikasi Masalah}

Apakah usaha pembibitan kelapa sawit pada UD.Jaya Tani di Kecamatan
Karang Baru Kabupaten Aceh Tamiang layak diusahakan dari segi analisis finansial?.

\section{Tujuan Penelitian}

Untuk menganalisis kelayakan finansial usaha pembibitan kelapa sawit pada UD.Jaya Tani di Kecamatan Karang Baru Kabupaten Aceh Tamiang dari segi analisis finansial.

\section{Hipotesis Penelitian}

Usaha pembibitan kelapa sawit pada UD.Jaya Tani di Kecamatan Karang Baru Kabupaten Aceh Tamiang layak diusahakan dari segi analisis finansial".

\section{METODOLOGI PENELITIAN Lokasi, Objek, Ruang Lingkup dan Waktu Penelitian}

Lokasi penelitianyaitu pada usaha pembibitan UD.Jaya Tani di Kecamatan Karang Baru Kabupaten Aceh Tamiang. Penelitian menggunakan metode survey. Metode penentuan lokasi penelitian yang digunakan dalam penelitian ini adalah metode studi kasus (case study). Menurut Susilo Rahardjo (2011:250) metode studi kasus ini mengungkapkan suatu kebenaran yang menitik beratkan hanya pada satu objek.

Objek dalam penelitian ini yaitu usaha pembibitan kelapa sawit pada UD.Jaya Tani di Kecamatan Karang Baru Kabupaten Aceh Tamiang. Ruang lingkup penelitian ini meliputi analisis kelayakan finansial usaha pembibitan kelapa sawit pada UD.Jaya Tani di Kecamatan Karang Baru Kabupaten Aceh Tamiang. Penelitian dilaksanakan pada bulan November s/d Desember 2017.

\section{Variabel dan Data Yang Dianalisis}
a. Tenaga kerja (HKP/Tahun)
b. Biaya produksi (Rp/Tahun)
c. Jumlah produksi (Bibit/Tahun)
d. Harga jual (Rp/Bibit)
e. Penerimaan (Rp/Tahun) 
f. Pendapatan (Rp/Tahun)

\section{Metode Analisis dan Pengujian Hipotesis}

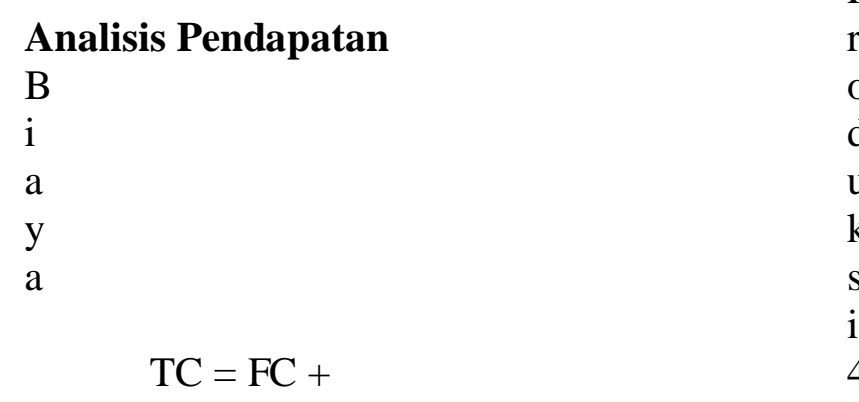

$\mathrm{VC}$ (Ken

Suratiyah, 2006:63)

Keterangan:

TC : Total biaya produksi (Rp/Tahun) FC : Biaya Tetap (Rp/Tahun)

VC : Biaya Variabel (Rp/Tahun)

Pendapatan Kotor

$\mathrm{TR}=(\mathrm{Y}) \mathrm{X}(\mathrm{Py})$ . Ken

Suratiyah, 2006:65)

Keterangan:

TR : Total penerimaan (Total Revenue) (Rp/Tahun)

Y : Produk yang diperoleh dalam usahatani (Bibit/ Tahun)

Py : Harga Y (Price) (Rp/Bibit)

Pendapatan Bersih

$\mathrm{Pd}=\mathrm{TR}-$

TC .(Soekartawi,

2002:58) Keterangan:

$\mathrm{Pd}=$ Pendapatan usahatani (Rp/Tahun)

$\mathrm{TR}=$ Penerimaan total (Total Revenue)

(Rp/ Tahun)

$\mathrm{TC}=$ Biaya total $($ Total Cost $)$

(Rp/Tahun)

\section{Pengujian Hipotesis}

Pengujian hipotesis dalam penelitian ini menggunakan analisis kriteria investasi yaitu:

1. NPV (Net Present Value)

2. Net Benefit-Cost Ratio (Net B/C)

3. Internal Rate of Return (IRR)
Data yang diperoleh dari lapangan baik data primer maupun data sekunder diolah dengan mentabulasikan dan kemudian dipindahkan ke dalam bentuk tabelaris sesuai dengan kebutuhan analisis. $\mathrm{P}$

r

d

$\mathrm{k}$

$\mathrm{S}$

4. Payback Period (PBP)

\section{HASIL DAN PEMBAHASAN \\ Karakteristik Pengusaha}

UD. Jaya Tani telah berdiri selama 10 tahun, nama pemilik usaha tersebut adalah Bapak Anwar Sayam. Umur pengusaha adalag 45 tahun, umur tersebut adalah umur yang produktif dalam menjalankan usaha pembibitan. Tingkat pendidikan terakhir pengusaha adalah 12 tahun (SMA), tingkat pendidikan tersebut tergolong sedang. Semakin tinggi pendidikan seseorang, maka semakin kreatif seorang pengusaha dalam mengambil berbagai tindakan usaha, begitu juga sebaliknya semakin rendah tingkat pendidikan seorang pengusaha maka semakin lambat dalam mengambil berbagai keputusan strategis usaha sehingga berpengaruh terhadap keberasilan usaha. Pengalaman berusaha adalah 10 tahun, pengalaman tersebut dalam usaha pembibitan tergolong cukup lama sehingga kegagalan dan resiko yang akan dihadapi akan semakin kecil dan dapat dikatakan cukup mahir dalam menjalankan usaha pembibitan. Jumlah tanggungan keluarga pengusaha adalah 2 orang menunjukan bahwa tergolong tanggungan yang kecil, sehingga pengusaha mampu mebiayai kebutuhan keluarga dan mengelola usaha dengan baik. 


\section{Luas Tempat Usaha}

Pengertian luas tempat usaha dalam penelitian ini adalah luas lahan yang digunakan pengusaha untuk menjalankan usaha pembibitan kelapa sawitpada UD. Jaya Tani Kecamatan Karang Baru. Hasil penelitian menunjukan bahwa luas tempat usaha pembibitan seluas adalah seluas 20 rante $(0,8$ hektar). Luas lahan ini sudah memadai untuk menjalankan usaha pembibitan yang memerlukan luas lahan yang tidak terlalu luas. Luas lahan yang paling luas digunakan untuk lahan pembibitan kelapa sawit adalah mainurcery(pembibitan utama) yang menggunakan polibeg besar sesuai jumlah permintaan.Sementara untuk luas lahan yang paling kecil adalah untuk pembibitan prenurcery (pembibitan awal) menggunakan polibeg kecil serta diberikan naungan untuk menghindari sinar matahari langsung dan curah hujan langsung agar bibit tidak rusak atau patah.

\section{Penggunaan Tenaga Kerja}

Tenaga kerja yang digunakan pada usaha pembibitan kelapa sawit UD. Jaya Tani terdiri dari tenaga kerja dalam keluarga (TKDK) dan tenaga kerja luar keluarga (TKLK) yang terdiri dari tenaga kerja pria dan wanita. Tenaga kerja pria mengerjakan kegiatan pengisian polibeg besar, penyusunan polibeg besar, pembersihan lahan, pembuatan naungan, pembuatan pagar, penyemprotan pestisida, penyiraman dan pengangkutan bibit ke truk. Tenaga kerja wanita mengerjakan kegiatan pengisian polibeg kecil, penanaman kecambah di polibeg kecil, penanaman bibit ke polibeg besar, penyiangan, pemupukan dan peyiraman. Sistem kerja pada UD. Jaya Tani dengan melihat situasi pekerjaan yang harus dikerjakan setiap hari. Rata-rata penggunaan tenaga kerja pada usaha pembibitan kelapa sawit UD. Jaya Tani dapat dilihat pada tabel V-1 berikut.

Tabel V-1. Rata-Rata Penggunaan Tenaga Kerja Usaha Pembibitan Kelapa Sawit UD. Jaya Tani di Kecamatan Karang Baru Tahun 2013-2017

\begin{tabular}{|c|c|c|c|}
\hline No & Tahun & Total Tenaga Kerja (Orang) & Biaya Tenaga Kerja (RP/Tahun) \\
\hline 1 & 2013 & 19,00 & $19.000 .000,00$ \\
2 & 2014 & 19,00 & $19.000 .000,00$ \\
3 & 2015 & 20,00 & $20.000 .000,00$ \\
4 & 2016 & 20,00 & $20.000 .000,00$ \\
5 & 2017 & 20,00 & $20.000 .000,00$ \\
\hline \multicolumn{2}{|c|}{ Total } & 98,00 & $98.000 .000,00$ \\
\hline
\end{tabular}

Sumber: Data primer diolah (2018)

Tabel V-1 menjelaskan bahwa penggunaan tenaga kerja pada usaha pembibitan kelapa sawit pada UD. Jaya Tani pada tahun 2013 sampai 2017 sebanyak 98 orang. Dengan upah tenaga kerja perorang sebesar Rp. 1.000.000,/bulan, dimana dalam 1 tahun rata-rata bekerja selama 10 bulan. Sehingga total biaya tenaga kerja selama tahun 20132017 sebesar Rp. 98.000.000,-.
Biaya investasi adalah biaya yang dikeluarkan sebelum usaha menghasilkan keuntungan. Biaya investasi meliputi biaya pembelian sarana dan prasarana usaha yang dipersiapkan pada saat usaha belum beroperasi dan barang investasi yang sudah habis umur ekonomisnya. Biaya investasi pada usaha pembibitan tanaman kelapa sawit pada UD. Jaya Tani dapat dilihat pada tabel V-2 berikut

\section{Biaya Investasi}


Tabel V-2. Biaya Investasi Usaha Pembibitan Kelapa Sawit pada UD. Jaya Tani di Kecamatan Karang Baru Tahun 2013-2017

\begin{tabular}{|c|c|c|}
\hline No & Tahun & Biaya Investasi (RP/Tahun) \\
\hline 1 & 2013 & $5.550 .000,00$ \\
2 & 2014 & $2.300 .000,00$ \\
3 & 2015 & $2.550 .000,00$ \\
4 & 2016 & $2.300 .000,00$ \\
5 & 2017 & $2.550 .000,00$ \\
\hline \multicolumn{2}{|c|}{} & $15.250 .000,00$ \\
\hline
\end{tabular}

Sumber: Data primer diolah (2018)

Tabel V-2 di atas menjelaskan bahwa biaya investasi pada usaha pembibitan kelapa sawit pada UD. Jaya Tani di Kecamatan Karang Baru selama tahun 2013-2017 adalah sebesar Rp. 15.250.000,-. Biaya investasi berbeda pada tahun 2013 sampai dengan tahun 2017 disebabkan karena ada sebagian barang-barang investasi ada yang sudah memasuki umur ekonomis harus dibeli kembali sehingga akan menambah biaya investasi.

\section{Biaya Operasional}

Biaya operasional usaha pembibitan kelapa sawit pada UD. Jaya Tani di Kecamatan Karang Baru terdiri dari biaya tetap dan biaya variabel. Biaya tetap meliputi sewa lahan dan penuyusutan. Sedangkan biaya variabel meliputi biaya pembelian tanah, tanah blendet, kecambah kelapa sawit, pupuk, pestisida, listrik, tenaga kerja dan polibeg. Biaya operasional adalah seluruh biaya untuk menjalankan operasional usaha pembibitan yang jumlahnya bisa berubah seiring dengan jumlah bibit yang akan dihasilkan. Jumlah bibit mengalami perubahan pada setiap tahun sejalan dengan jumlah permintaan dari konsumen serta kontrak yang disepakati antara pihak pengusaha dan konsumen. Biaya produksi pada usaha pembibitan kelapa sawit pada UD. Jaya Tani di Kecamatan Karang Baru dapat dilihat pada tabel V-3 berikut.

Tabel V-3. Biaya Operasional Usaha Pembibitan Kelapa Sawit pada UD. Jaya Tani di Kecamatan Karang Baru Tahun 2013-2017

\begin{tabular}{|c|c|c|}
\hline No & Tahun & Biaya Operasional (RP/Tahun) \\
\hline 1 & 2013 & $62.383 .500,00$ \\
2 & 2014 & $60.387 .500,00$ \\
3 & 2015 & $60.916 .000,00$ \\
4 & 2016 & $61.815 .000,00$ \\
5 & 2017 & $62.080 .000,00$ \\
\hline \multicolumn{2}{|c|}{} & Total \\
\hline
\end{tabular}

Sumber: Data primer diolah (2018)

Tabel V-3 menunjukkan bahwa total biaya operasional usaha pembibitan kelapa sawit pada UD. Jaya Tani di Kecamatan Karang Baru tahun 2013 s/d
2017 sebesar Rp.307.582.000,00. Biaya operasional terbesar terjadi pada tahun 2013 sebesar Rp.62.383.500,00 dan biaya operasional terkecil terjadi pada tahun 
2014 sebesar Rp.60.387.500,00. Hal ini disebabkan oleh jumlah bibit kelapa sawit yang diproduksi berubah-ubah sesuai permintaan konsumen.

\section{Produksi Bibit Kelapa Sawit}

Produksi usaha pembibitan kelapa sawit pada UD. Jaya Tani di Kecamatan Karang Baru berupa bibit yang berumur
8 bulan. Produksi diakumulasikan dalam waktu satu tahun, jadi periode penanaman kecambah kelapa sawit berlangsung beberapa kali dalam satu tahun. Produksi bibit usaha pembibitan kelapa sawit pada UD. Jaya Tani di Kecamatan Karang Baru dapat dilihat pada tabel V-4 berikut ini.

Tabel V-4. Produksi Usaha Pembibitan Kelapa Sawit pada UD. Jaya Tani di Kecamatan Karang Baru Tahun 2013-2017

\begin{tabular}{|c|c|c|}
\hline No & Tahun & Jumlah Bibit (Bibit) \\
\hline 1 & 2013 & $5.800,00$ \\
2 & 2014 & $5.900,00$ \\
3 & 2015 & $5.750,00$ \\
4 & 2016 & $5.800,00$ \\
5 & 2017 & $5.775,00$ \\
\hline \multicolumn{2}{|c|}{} & $29.025,00$ \\
\hline
\end{tabular}

Sumber: Data primer diolah (2018)

Tabel V-4 menunjukkan bahwa total produksi usaha pembibitan kelapa sawit pada UD. Jaya Tani di Kecamatan Karang Baru tahun 2013 s/d 2017 sebesar 29.025,00 bibit kelapa sawit. Produksi terbesar terjadi pada tahun 2014 sebesar 5.900 bibt dan produksi terkecil terkecil terjadi pada tahun 2015 sebesar 5.750,00 bibit. Hal ini disebabkan oleh jumlah bibit kelapa sawit yang diproduksi berubah- ubah sesuai permintaan konsumen dan juga disebabkan oleh bibit yang mati atau terserang hama serta penyakit.

\section{Nilai Produksi (Penerimaan) Usaha}

\section{Kecamatan Karang Baru Tahun 2013-2017}

\begin{tabular}{|c|c|c|c|c|}
\hline No & Tahun & $\begin{array}{c}\text { Jumlah Bibit } \\
\text { (Bibit) }\end{array}$ & $\begin{array}{c}\text { Harga Bibit } \\
\text { (Rp/Bibit) }\end{array}$ & Nilai Produksi (Rp) \\
\hline
\end{tabular}

Nilai produksi (penerimaan) adalah total perkalian produksi dan harga produksi yang diterima pengusaha dari usaha pembibitan kelapa sawit pada UD. Jaya Tani di Kecamatan Karang Baru.Nilai produksi sangat ditentukan oleh harga yang berlaku pada saat pengusaha menjual bibitnya. Nilai produksi disebut juga pendapatan kotor karena belum dikurangi dengan total biaya produksi, jadi pendapatan kotor belum dapat dijadikan alat ukur untuk menentukan suatu usaha untung atau rugi. Nilai produksi usaha pembibitan kelapa sawit pada UD. Jaya Tani di Kecamatan Karang Baru dapat dilihat pada tabel V-5 berikut ini.
Tabel V-5. Nilai Produksi Usaha Pembibitan Kelapa Sawit pada UD. Jaya Tani di 


\begin{tabular}{|l|l|l|l|l|}
\hline 1 & 2013 & $5.800,00$ & $15.000,00$ & $87.000 .000,00$ \\
2 & 2014 & $5.900,00$ & $15.000,00$ & $88.500 .000,00$ \\
3 & 2015 & $5.750,00$ & $15.000,00$ & $86.250 .000,00$ \\
4 & 2016 & $5.800,00$ & $15.000,00$ & $87.000 .000,00$ \\
5 & 2017 & $5.775,00$ & $15.000,00$ & $86.625 .000,00$ \\
\hline \multicolumn{2}{|c|}{ Total } & $29.025,00$ & & $435.375 .000,00$ \\
\hline
\end{tabular}

Sumber: Data primer diolah (2018)

Tabel V-5 menunjukkan bahwa total nilai produksi usaha pembibitan kelapa sawit pada UD. Jaya Tani di Kecamatan Karang Baru tahun 2013 s/d 2017 sebesar Rp. 435.375.000,00. Nilai produksi terbesar terjadi pada tahun 2014 sebesar Rp. 88.500.000,00 dan nilai produksi terkecil terkecil terjadi pada tahun 2015 sebesar Rp. 86.250.000,00. Hal ini disebabkan oleh jumlah bibit kelapa sawit yang diproduksi berubah-ubah sesuai permintaan konsumen dan juga disebabkan oleh bibit yang mati atau terserang hama serta penyakit.

\section{Pendapatan Bersih Usaha}

Pendapatan bersih adalah total penerimaan dikurangi oleh total biaya yang dikeluarkan oleh pengusaha dari usaha pembibitan kelapa sawit pada UD. Jaya Tani di Kecamatan Karang Baru. Pendapatn bersih sangat ditentukan oleh harga, produksi dan biaya produksi. Pendapatan bersih dapat dijadikan alat ukur untuk menentukan suatu usaha untung atau rugi. Usaha dalam keadaan untung jika total penerimaan lebih besar dari total biaya, Pendapatan bersih usaha pembibitan kelapa sawit pada UD. Jaya Tani di Kecamatan Karang Baru dapat dilihat pada tabel V-7 berikut ini.

Tabel V-7. Pendapatan Bersih Usaha Pembibitan Kelapa Sawit pada UD. Jaya Tani di Kecamatan Karang Baru Tahun 2013-2017

\begin{tabular}{|c|c|c|c|c|}
\hline No & Tahun & $\begin{array}{c}\text { Nilai Produksi } \\
(\text { Rp/Tahun) }\end{array}$ & $\begin{array}{c}\text { Biaya Operasional } \\
\text { (Rp/Tahun) }\end{array}$ & $\begin{array}{c}\text { Pendapatan } \\
\text { (Rp/Tahun) }\end{array}$ \\
\hline 1 & 2013 & $87.000 .000,00$ & $62.383 .500,00$ & $24.616 .500,00$ \\
2 & 2014 & $88.500 .000,00$ & $60.387 .500,00$ & $28.112 .500,00$ \\
3 & 2015 & $86.250 .000,00$ & $60.916 .000,00$ & $25.334 .000,00$ \\
4 & 2016 & $87.000 .000,00$ & $61.815 .000,00$ & $25.185 .000,00$ \\
5 & 2017 & $86.625 .000,00$ & $62.080 .000,00$ & $24.545 .000,00$ \\
\hline \multicolumn{2}{|r|}{ Total } & $435.375 .000,00$ & $307.582 .000,00$ & $127.793 .000,00$ \\
\hline
\end{tabular}

Sumber: Data primer diolah (2018)

Tabel V-7 menunjukkan bahwa total pendapatan bersih usaha pembibitan kelapa sawit pada UD. Jaya Tani di Kecamatan Karang Baru tahun 2013 s/d 2017 sebesar Rp.127.793.000,00. Pendapatan bersih terbesar terjadi pada tahun 2014 sebesar Rp.28.112.500,00 dan pendapatan bersih terkecil terjadi pada tahun 2017 sebesar Rp.24.545.000,00. Hal ini disebabkan oleh jumlah bibit kelapa sawit yang diproduksi, nilai produksi dan biaya produksi berubahubah sesuai permintaan konsumen dan juga disebabkan oleh bibit yang mati atau terserang hama serta penyakit.

Analisis Kelayakan Finansial Usaha Pembibitan Kelapa Sawit pada UD. Jaya Tani di Kecamatan Karang Baru 
Untuk menganalisis apakah usaha pembibitan kelapa sawit pada UD. Jaya Tani di Kecamatan Karang Baru layak atau tidak layak untuk dikerjakan maka dilakukan analisis kelayakan finansial dengan 4 (empat) kriterian penilaian investasi yaitu: NPV, Net B/C, IRR dan PBP. Hasil analisis kelayakan finansial usaha pembibitan kelapa sawit pada UD. Jaya Tani di Kecamatan Karang Baru dapat dilihat pada tabel V-7 berikut.

Tabel V-7. Hasil Analisis Kelayakan Finansial Usaha Pembibitan Kelapa Sawit pada UD. Jaya Tani di Kecamatan Karang Baru

\begin{tabular}{|c|l|c|c|c|}
\hline No & \multicolumn{1}{|c|}{$\begin{array}{c}\text { Kriteria } \\
\text { Investasi }\end{array}$} & Hasil Analisis & $\begin{array}{c}\text { Kriteria } \\
\text { Penerimaan }\end{array}$ & Kesimpulan \\
\hline 1 & NPV & Rp. $187.484 .268,96$ & $>0$ & Layak \\
2 & IRR & $14,42 \%$ & $>12 \%$ & Layak \\
3 & Net B/C & 1,57 & $>1$ & Layak \\
4 & PBP & 1,36 Tahun & $<5$ Tahun & Layak \\
\hline
\end{tabular}

Sumber: Data primer diolah (2018)

Tabel V-7 menjelaskan bahwa hasil analisis kelayakan finansial untuk 4 (empat) penilaian kriteria investasi semuanya layak. Nilai NPV sebesar Rp.187.484.268,96 adalah lebih besar dari 0 maka dari sisi NPV usaha pembibitan kelapa sawit pada UD. Jaya Tani di Kecamatan Karang Baru layak untuk dikerjakan. Artinya usaha pembibitan kelapa sawit pada UD. Jaya Tani di Kecamatan Karang Baru menguntungkan secara finansial.

Nilai IRR sebesar $14,42 \%$ adalah lebih besar dari $12 \%$ maka dari sisi IRR usaha pembibitan kelapa sawit pada UD. Jaya Tani di Kecamatan Karang Baru layak untuk dikerjakan. Artinya pengembalian yang diterima pengusaha lebih besar dari bunga bank yang berlaku atau usaha tersebut menguntungkan.

Nilai Net B/C sebesar 1,56 adalah lebih besar dari 1 maka dari sisi Net B/C usaha pembibitan kelapa sawit pada UD. Jaya Tani di Kecamatan Karang Baru layak untuk dikerjakan. Artinya bahwa manfaat bersih yang diterima oleh pengusaha lebih besar dari total biaya yang dikeluarkan yang didiskontokan.

Nilai PBP sebesar 1,36tahun adalah lebih kecil dari 5tahu maka dari sisi PBP usaha pembibitan kelapa sawit pada UD. Jaya
Tani di Kecamatan Karang Baru layak untuk dikerjakan. Artinya masa pengembalian 1,36 tahun lebih kecil dari umur proyek yaitu 5 tahun.

\section{KESIMPULAN DAN SARAN Kesimpulan}

1. Hasil analisis kelayakan finansial untuk 4 (empat) penilaian kriteria investasi usaha pembibitan kelapa sawit pada UD. Jaya Tani di Kecamatan Karang Baru semuanya layak.

2. Nilai NPV sebesar Rp. 187.484.268,96 adalah lebih besar dari 0 maka dari sisi NPV usaha pembibitan kelapa sawit pada UD. Jaya Tani di Kecamatan Karang Baru layak untuk dikerjakan. Artinya usaha pembibitan kelapa sawit pada UD. Jaya Tani di Kecamatan Karang Baru menguntungkan secara finansial.

3. Nilai IRR sebesar $14,42 \%$ adalah lebih besar dari $12 \%$ maka dari sisi IRR usaha pembibitan kelapa sawit pada UD. Jaya Tani di Kecamatan Karang Baru layak untuk dikerjakan. Artinya pengembalian yang diterima pengusaha lebih besar 
dari bunga bank yang berlaku atau usaha tersebut menguntungkan.

4. Nilai Net $B / C$ sebesar 1,56 adalah lebih besar dari 1 maka dari sisi Net B/C usaha pembibitan kelapa sawit pada UD. Jaya Tani di Kecamatan Karang Baru layak untuk dikerjakan. Artinya bahwa manfaat bersih yang diterima oleh pengusaha lebih besar dari total biaya yang dikeluarkan yang didiskontokan.

5. Nilai PBP sebesar 1,36 tahun adalah lebih kecil dari 5 tahu maka dari sisi PBPusaha pembibitan kelapa sawit pada UD. Jaya Tani di Kecamatan Karang Baru layak untuk dikerjakan. Artinya masa pengembalian 1,36 tahun lebih kecil dari umur proyek yaitu 5 tahun.

\section{Saran}

1. Disarankan kepada pengusaha usaha pembibitan kelapa sawit pada UD. Jaya Tani di Kecamatan Karang Baru dapat memperluas pemasaran bibit kelapa sawit, agar pendapatan dapat meningkat dimasa yang akan datang

2. Perlu adanya perhatian pemerintah agar memberikan akses pasar, modal dan pengembangan usaha pembibitan kelapa sawit pada UD. Jaya Tani di Kecamatan Karang Baru menjadi lebih besar.

\section{DAFTAR PUSTAKA}

Daniel, 200 I. Manajemen Pemasaran, Jilid Satu dan Dua Alih Bahasa Oleh David Octarevia, Salemba Empat, Jakarta.

Hadisapoetra, 2000. Biaya dan Pendapatan di Dalam Usohatani. UGM. Yogyakarta
Hernanto, F., 2004. Ilmu Usahatanl: Penebar Swadaya. Jakarta. Ibrahim. Yakob. 2003. Studt Kelayakan Oisnis. Bineka Cipta. Jakarta.

Kadariah, 2001. Evaluasl Proyek : Analisls Ekonomis. Lembaga Penerbium Fakultas Ekonomi Universitas Indonesia, Jakarta

Mubyarto, 2002. Pengantar Ekonomi Pertanian. LP3ES. Jakarta.

Nusmawnrhaeni, 200 I. Mengenal Buah Unggu/ Indonesia. Cetakan IX. Penebar Swadaya. Jakarta

Rangkuti, 2012. fe/mlk Membedah Kasus Bisnls. Salemba Empal. Jakarta

Siregar, Tumpal, H.S. 2008. Budidaya Tanaman Perkebunan. Penebar Swadaya, Jakarta

Setiawan. 2000. Pengantar Produksi Benih. Rajawali Press. Jakarta

Soekartawi, 2002. Ilmu Usahatani don Penelitian Umuk Pengembangan Petani Kecil, Penerbit Universitas Indonesia, Jakarta

Soetriono, AS. 2001. Pengamar Llmu Per/anion: Agrarls, AgrobisnIs dan Industri. Malang: Baywnedia.

Suprapto, 2003. Karakterisnk: Penerapan; dan Pengembangan Agroindustri Hasil Pertanian di Indonesia. Jakarta. Universitas Mereu Buana,

Suratiyah, Ken. 2006. IImu Usahatani. Cetakan I. Jakarta: Penerbit Penebar Swadaya

Sutojo. 2000. Strategi Manajemen Kredit Bank Mumum. PT. Damar MuLia Pustaka, Jakarata

Tobar. (2000). Membuka Usaha Kecil . Yogyakarta: Kanisius

Umar, H. 2003. Melode Riset Btsnis, PT Gramedia Pustaka Utama, Jakarta

Umar, 2007. Metode Studt Kelayakan Bisnls, PT Gramedia Puslaka Utama. Jakarta

Winamo. 2002. Teart Kebijakan Bisnls

UGM Unh-ersiity. Yokyakarta 
